\title{
The Psychology of Hatred
}

\author{
José I. Navarro*, Esperanza Marchena and Inmaculada Menacho
}

Department of Psychology, University of Cadiz, Spain

\begin{abstract}
Hatred is a deep and emotional extreme dislike. The objects of such hatred can vary extensively. Hatred is often associated with disposition towards hostility against the objects of hatred. And can drive oneself to extreme behaviors such as violence, murder, and war. In childhood and adolescence the attitudes of intolerance - impregnated with hatred are formed, and these are extremely difficult to eradicate later. This paper goes through psychological perspective of hate and the different roles of cognition in hatred and violence. Then the duplex theory of hatred is presented considering some approaches to the origin of violent behaviors. Taking into consideration that complex problems do not respond to simple solutions, a potential alternative based on family and school education plays a major role. Learning conflict resolution based on negotiation and compromise seems essential, in addition to adopting intellectually and morally combative attitudes against violence.
\end{abstract}

Keywords: Hatred, violence, cognition, automatic thoughts.

\section{INTRODUCTION}

Hatred is a strong, negative feeling against the object of the hatred. The hater sees the object of their hatred as bad, immoral, dangerous, or all of this together (Staub, 2003). A violent act is also an act of hatred, when it is based on an intense, persistent and negative perception of the other, who we intend and desire to hurt, destroy, or even make suffer. Hatred is based on the perception of the other, but also has a strong relationship with ourselves, with our personal history, and its effects on our personality, feelings, ideas, beliefs, and especially our identity. Certain adversity in our lives can trigger and intensify hatred: jealousy, failure, guilt and so on.

Jose-Luis-Lopez-de-Lacalle, an old militant Basque leftwinger under Franco dictatorship and founder of the antiviolence Ermua Forum, was shot dead by some young ETA militant. He was on his way back from buying the Sunday papers and was shot near the door of his house. This occurred in Andoain, his home town, on May 7 2000, where a few hours after the crime, the village was daubed with graffiti saying "De Lacalle, fuck you, murderer!" (Echeburua, 2000).

In the Israeli-Palestinian conflict, we have sometimes seen distressing images of extreme racial hatred, more than that expected even in a war. For example, during the second intifada, Palestinian children in the Gaza Strip left school to stone the armoured vehicles of the Israeli army. Once the soldiers detained a nine-year-old boy and beat the child's arms with batons, breaking them at various points. This ensured that he wouldn't throw stones again. These images were seen around the world: two burly soldiers breaking the arms of a nine-year-old child for the heinous crime of throwing stones at a tank.

*Address correspondence to this author at the Department of Psychology, University of Cadiz, Puerto Real-Cadiz (Spain); CP: 11510.

Tel: +34 956016 217; Fax: +34 956016 253; E-mail: jose.navarro@uca.es
Although most people are disgusted by the exercise of violence, there are certain circumstances in which any of us could do it. But it is hard to imagine how you can reach the level of cruelty shown by the graffiti in Andoain, besides the enormous indifference - and perhaps joy - shown towards human pain.

Prejudice, group hostility and hatred are everyday experiences. They are expressed in words and in deeds. US white supremacists attack blacks; Jews kill Palestinians, and the latter blow themselves up in a Jerusalem restaurant full of Jewish diners; pro-abortion gynaecologists have been murdered by anti-abortion fanatics; the genocides of Rwanda and Bosnia; the terrorist massacres in the USA of 11th September; the 11th March atrocities in Madrid ...

Not every act of violence arises out of hate. Violence can be instrumental; sometimes we act violently against others to achieve a goal. Or it may be defensive, or hostile (for example when someone is frustrated or attacked, and reacts violently).

Hatred is a strong, negative feeling against the object of the hatred. The hater sees the object of their hatred as bad, immoral, dangerous, or all of this together (Staub, 2003). A violent act is also an act of hatred, when it is based on an intense, persistent and negative perception of the other, who we intend and desire to hurt, destroy, or even make suffer. Hatred is based on the perception of the other, but also has a strong relationship with ourselves, with our personal history, and its effects on our personality, feelings, ideas, beliefs, and especially our identity. Certain adversity in our lives can trigger and intensify hatred: jealousy, failure, guilt and so on.

In short, hatred is built on a complex mix of cognitions and emotions. The cognitive components are related to the devaluation of the other, the perception of them as a threat. The emotional part includes a set of feelings like anger, fear, 
distress, and hostility. Finally, another element related to hatred is a certain, sometimes crazy, sense that we are justified in acting against - or even eliminating - the object of our hate.

In this paper we describe the development of hatred, and then explain relations between hatred, violence and anger: Finally how cognition establishes connection with emotions like the hate is explained.

\section{EMPATHY AND VIOLENCE}

When we are very young, we develop an ability to empathize, to put ourselves in the place of other people, as one of our emotional development mechanisms. That capacity allows us understand what others are feeling, and where their suffering or joy comes from. This feeling ends up being a conscious ethical commitment conscious ethical commitment (Caliskan \& Boratav, 2011).

Adults are intolerant towards violent behaviour in young children, and towards expressions of hatred towards others. Both at school and in the family, physically aggressive behaviours in children are usually punished by parents or teachers in one way or another. As we develop and gain language proficiency, we quickly learn that the spoken word sometimes has as disturbing an effect as a fist. Children soon learn that an insult is often as effective as a punch, or pulling your opponent's hair. This development can be so sophisticated that we even have gained some forms of verbal aggression of great subtlety, e.g. irony. It is said that Winston Churchill was once arguing in the British parliament with an opposition MP. At one moment, the MP got up from her seat and chided Churchill, saying:

- $\quad$ "Mr. Churchill, if I were your wife, I would make you a cup of poisoned tea."

To which Churchill answered

\section{- Madam, if I were your husband, I would drink it!"}

The emotional world of human symbolic keys also works on the basis of the development of what we have come to call the theory of the mind (Meltzoff, 2011). That's why we laugh at the story; we laugh at the irony. This theory suggests that others (the others) have a mental world of intentions and desires, which are not seen, but which we can guess; we can intuit. We have the ability to read that mental world. Today we know much more about the cognitive functioning of our brain, and it is clear that the cognitive components of our emotions are essential to understanding such emotions. Those people who, as a result of a particular pathology, lack the theory of the mind - as happens to autistic people, for example - teach us much about how we learn to read the emotions of others. This system full of symbolic codes allows us to express a lot of emotions that we would not otherwise exteriorize - something that autistic children find particularly difficult (Shimoni, Weizman, Yoran, \& Raviv 2012); so we get excited, and even feel panic, watching a movie, even knowing it's fiction; or we identify with a character in the novel we are reading. Clearly it is not the same being the protagonist of an emotional situation as being a spectator, but the symbolic processes that are triggered whilst being a spectator help us dilute or exteriorize many of our emotions, which is essential for our mental balance. Autistic children lack or are deficient in these symbolic encoding mechanisms, hence their emotional reactions are very sketchy, unpredictable, and sometimes aggressive, even towards themselves.

The theory of the mind also allows us to have anticipation schema, i.e., we have some ability to predict the future. So, today at $5 \mathrm{pm}$, Dr. Vicente Garrido has a lecture, therefore he is likely to be in the classroom afterwards; there is no course on Thursday, then students likely will not be there. My plane leaves for Cadiz this afternoon, so I'll be at the airport, and so on. This is also related to other complex mental processes such as prospective memory, i.e. the ability to remember things we have planned previously: next Thursday I have an appointment with the dentist; at 9 I must take my pills; tomorrow I have a meeting at 11 . This type of memory is severely impaired in patients with Alzheimer's disease and other dementias. Anticipation schema give us more mental flexibility, which is why autistic children need order and inflexibility in their environment. When this order is modified, it is very distressing for them because order allows them to make their environment predictable.

\section{HATRED DEVELOPMENT}

Sometimes intense violence develops gradually (Salzinger, Feldman, \& Stockhammer, 2002). Hatred also develops step by step. When a person does harm to another (for example, one partner hits the other), or members of a group harm another group which is slightly different (e.g. discriminating against someone in an educational setting, or exploiting someone at work), feelings of hatred may start to develop.

One of the characteristics of hatred is the need to devalue the victim more and more (Staub, 2005). At the end of the process, the object of the hatred loses all moral or human consideration in the eyes of the hater. When hatred intensifies, a certain fanatical obligation to get rid of the person or group that is the object of the hatred can easily arise (Opotow, 1990). Getting rid of that person sometimes means inflicting considerable damage or, taking it to an extreme, physical disappearance or murder: a frequent recourse in situations of intense hatred. In the end, it can produce a reversal of the moral code: killing the hated person or group is a right. The history of mankind is full of such examples: deportations of potential enemies by Stalin; ethnic cleansing in the Balkans war; the many cases of domestic violence ending in the murder of the partner.

There are two factors at the root of hatred: the devaluation of the victim and the ideology of the hater. Both of these factors mould and expand hatred. They reduce empathy, because the hater moves increasingly away from the object of their hatred. They remove obstacles that could limit our hatred towards others, by transforming our feelings into hatred. They not only change our ideas and feelings, but even the social norms that guide our behaviour towards the object of our hatred. The new behaviour ends up being accepted and normal; and institutions may even be created to promote and spread hatred. Palestinian children learn to hate Jews at school and Jewish radicals do the same with their children; Saharan children are taught to hate Moroccans; 
sometimes in the Basque Ikastolas, history is distorted to justify the existence of the Spanish invaders. We could continue with examples from everywhere.

\section{HATRED AS EMOTION}

Anger is a complex emotion, and its formation is not simple. For example, Christianity has defended loving one another as a source of motivation to save the souls of nonbelievers. In fact, this implies devaluing the beliefs of nonbelievers (their faith is false, they are possessed by the devil ...). In the process of conversion to Christianity, we inflicted terrible cruelty on the "infidels", especially when they resisted (see Spaniards campaigns in America, the Crusades against the infidels). Resistance to Christianization increased feelings of devaluation towards the Indian infidel, and facilitated their discrimination and persecution ... all elements of the evolution of hate.

Hatred can also be an individual matter. You can hate someone for the experiences we have had with him/her; the friend who betrayed us. And hatred can be shared as well. A terrorist cell or an ethnic, religious or political group share a vision, attitudes and feelings towards others. The example of anti-Semitic groups in Nazi Germany is particularly telling. The group dynamic forces the devaluation of the other; feelings become contagious; negative thoughts about the other are shared; and make it easier to hate. Negative feelings expressed by a crowd towards someone of a rival group (in football, for example), can escalate and trigger a collective response to the opposing group.

Sometimes strong leadership can spark the fire of hatred. Ezekiel (2002) describes how leaders of the US White Supremacist group are very interested in power, but have very little interest in people, including their own followers, who are treated with great cynicism. Feelings of closeness or love are seen as indicators of weakness. In this process of the development of hatred that passes through devaluation of the other, discrimination, and violence against them, the followers come to identify with the leaders and the ideology they propagate. Once this occurs, hatred does not remain under the control of the leader. In these conditions, it is difficult to know where it will end. We consider the experience of the Rwandan genocide which lasted 100 days in 1994: 800,000 Tutsi ( $10 \%$ of the population of Rwanda) were killed at the hands of the Hutu majority.

\section{THE ROLE OF COGNITION IN HATRED}

When we consider the amount of violence between family members, the tragedy of the two World Wars and the many local ones, terrorist attacks or the genocides we have seen happen, we become aware that the harm that humans can do to each other represents a serious threat to us. Theorists from Freud to the present day have faced the difficult task of understanding the reason for hatred and violence (Post, 2005). In recent decades, the cognitive-behavioural perspective has provided a useful explanation, and the hope that it may lead to strategies for prevention and intervention.

The cognitive perspective developed from the intuition that people's thoughts strongly influence their emotional responses and behaviour. Ideas of rejection, failure or loss make us feel sad and we have a tendency to get carried away by such feelings. Ideas of achievement, success and approval from others encourage us to keep going. Ideas of danger or fear drive us to be anxious and to do something to prevent it. The thought of being wrong or of being mistreated produces anger and impels us to seek revenge. These ideas are floating in our minds, are involuntary, and sometimes are not recognized by people until a good therapist teaches them to look closely at these automatic thoughts (Beck, 2005). In short, thoughts sometimes trigger very strong emotional reactions, and have a significant impact on behaviour.

Another interesting observation is that automatic thoughts play an important role in emotional problems, and are often completely out of proportion to the problem posed. They are usually disproportionate or exaggerated interpretations of actual events. Two factors make this possible:

1. Humans are subject to a high risk of errors in our thinking (cognitive distortions) that can have a major impact on how the individual interprets what happens. For example, people with a tendency to be angry tend to interpret what happens with other people in an egocentric way (Why does this have to happen to me?) and they often exaggerate the frequency of adverse events (She never shows me any respect)

2. We interpret what happens to us in terms of certain beliefs and preconceptions that we have gained from our previous experience. These may include certain unconditional beliefs (I am not important to anyone), others are conditioned (If I do not make myself respected, I am no-one), or interpersonal strategies (I have to make people respect me).

These beliefs lie dormant until a major event occurs, and they then trigger and shape our behaviour. These dysfunctional beliefs may influence what aspects of a situation we focus on more; how we interpret that experience; and how we respond to it.

Clinical observations show that in patients who are led by their exaggerations and misinterpretations, emotional reactions and behaviour are in proportion to these distortions of their thoughts. However, when they learn to focus their attention on their automatic thoughts, to look at them with a critical eye, and intentionally replace them with more realistic ones, they start to take advantage of and learn to deal with their emotional problems (Fig. 1). For example, when a mother who is easily provoked by her children can recognize her thinking: "My kids are bad, they make my life hell, I have to punish them", and replace it with: "They behave like all children of their age", she may experience that her anger is less intense and disappears more quickly.

Ultimately the emerging cognitive model of patient observation and research suggests that ideas are an important element of a cycle in which thoughts influence feelings and these influence behaviour, and that these actions then influence feelings and thoughts (Anderson, Carnagey, \& Eubanks, 2003). It is not correct to assert that thoughts cause feelings, and in turn reactions.

Some of these cognitive distortions are very common and can trigger feelings of hatred and extremely violent reactive behaviours. Let us consider some of the most common: 


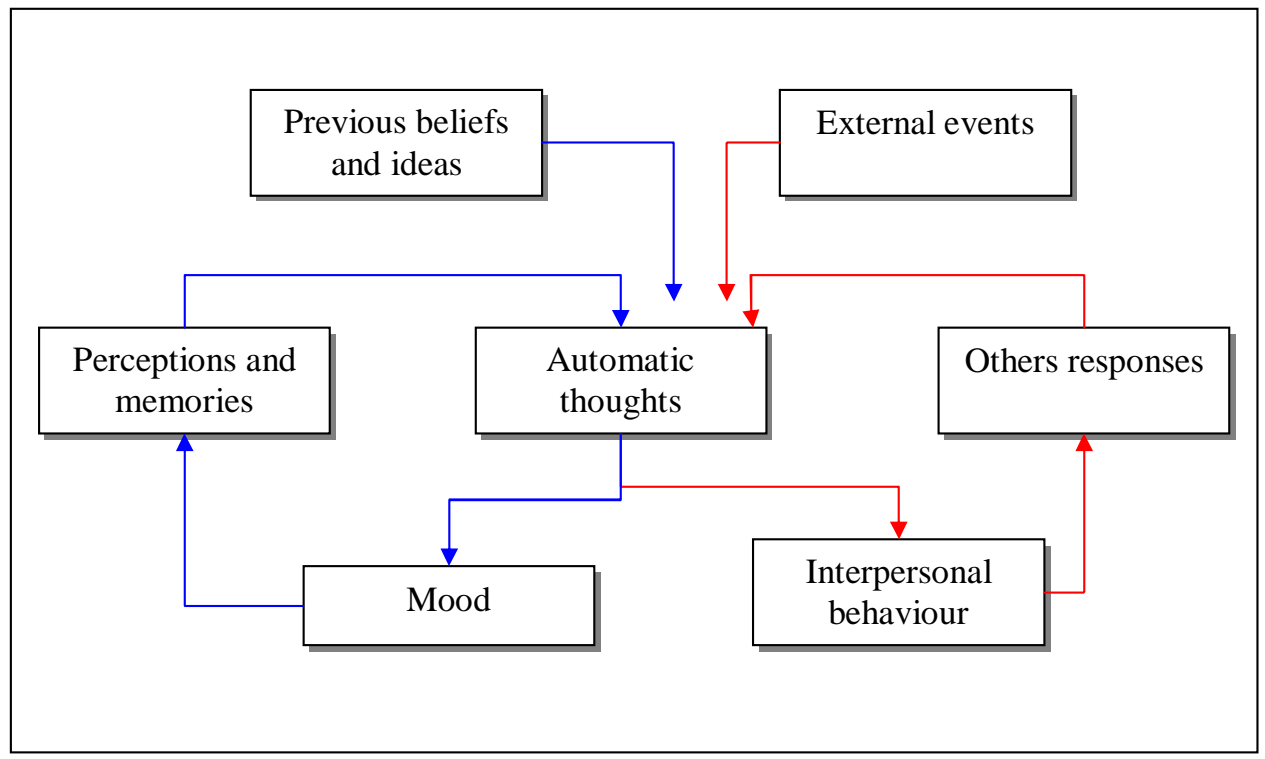

Fig. (1). The automatic thoughts cycle (after Beck \& Pretzer, 2005, p. 70).

Overgeneralization: a particular event is perceived as characteristic of life in general, not just one event of many. For example, concluding that a single nasty response shows that his wife does not care about him at all, even though on many other occasions she has been attentive and considerate to him.

Read the thought: assuming that one knows what the other is thinking, or how they will react, despite having little or no evidence for it. For example, "He is going to leave me, I know it" and act as if it were definitely true.

Emotional reasoning: assuming one's emotional reactions necessarily reflect a real situation. For example, concluding that because you feel desperate at one point, the situation is really desperate.

Customization: assuming that one is the cause of an event, when in fact there are many other factors responsible. For example, "He was not very nice to me today, he must be angry with me," without considering different factors that could have affected his mood that day.

Maximization or minimization: treating some aspects of the situation, personal characteristics and experiences as trivial and others as very important, regardless of their actual significance. For example, "I know that people respect my work, but it does not matter because my wife does not respect me in the least."

Catastrophic thinking: treating current negative events as catastrophic, without putting them into perspective. For example, thinking "Oh my God, I've got a lump in my breast, I'm sure I have cancer and I'm going to die like my neighbour."

\section{A COGNITIVE MODEL}

The cognitive perspective may explain why the mother who is tense ends up angry with her child, but it is not so good at helping us understand hatred and violence. We all feel angry from time to time, but this momentary experience does not end in an episode of hatred and violence. Most people who are very angry about their work, their relationships with their family or with their friends do not end up hitting them or shooting wildly at anything that moves.

In 2000, at Columbine High School, Colorado (USA) two teenagers committed what is called a mass murder against their peers and teachers at their own school. It was a long-planned action as the police later discovered, that could have been even more tragic than it was.

What happens so that we can convince ourselves of the legitimacy of our violent response? Family violence can be a excellent frame to explain why this response occurs. The following sequence summarizes how domestic violence may occur (Fig. 2):

If the man interprets his wife's comments in a way that makes him feel undermined, hurt or misunderstood, this creates stress or self dislike. If he interprets her behaviour as unjustified and inexcusable, he will probably feel like a victim of his wife's abuse, he will feel angry, and it will be easier to be driven to suppress and punish her. The greater amount of cognition in that direction, the more convinced he will be of the legitimacy of a violent response and the more likely he will be to respond in that way (Beck, 2002).

There is "hot" violence and "cold" violence. The first is associated with an episode of anger or rage, but has no planning or preparation. The individual feels hostility towards the victim and this makes a violent response more likely. In many situations of "hot" violence, both the perpetrator and the victim often view violence as justified. So when an individual or group feels it has been maligned, damaged, or has suffered coercion, deceit, or corruption by another, the answer is an impulse to commit violence, revenge, or destruction of the source of corruption. In addition, there are beliefs that increase and further justify such reactions: "Do not get angry, act", "God is on our side", "It's them or us", and may increase the perception that violence is necessary and justified. When the individual is demonized (different, infidel, 


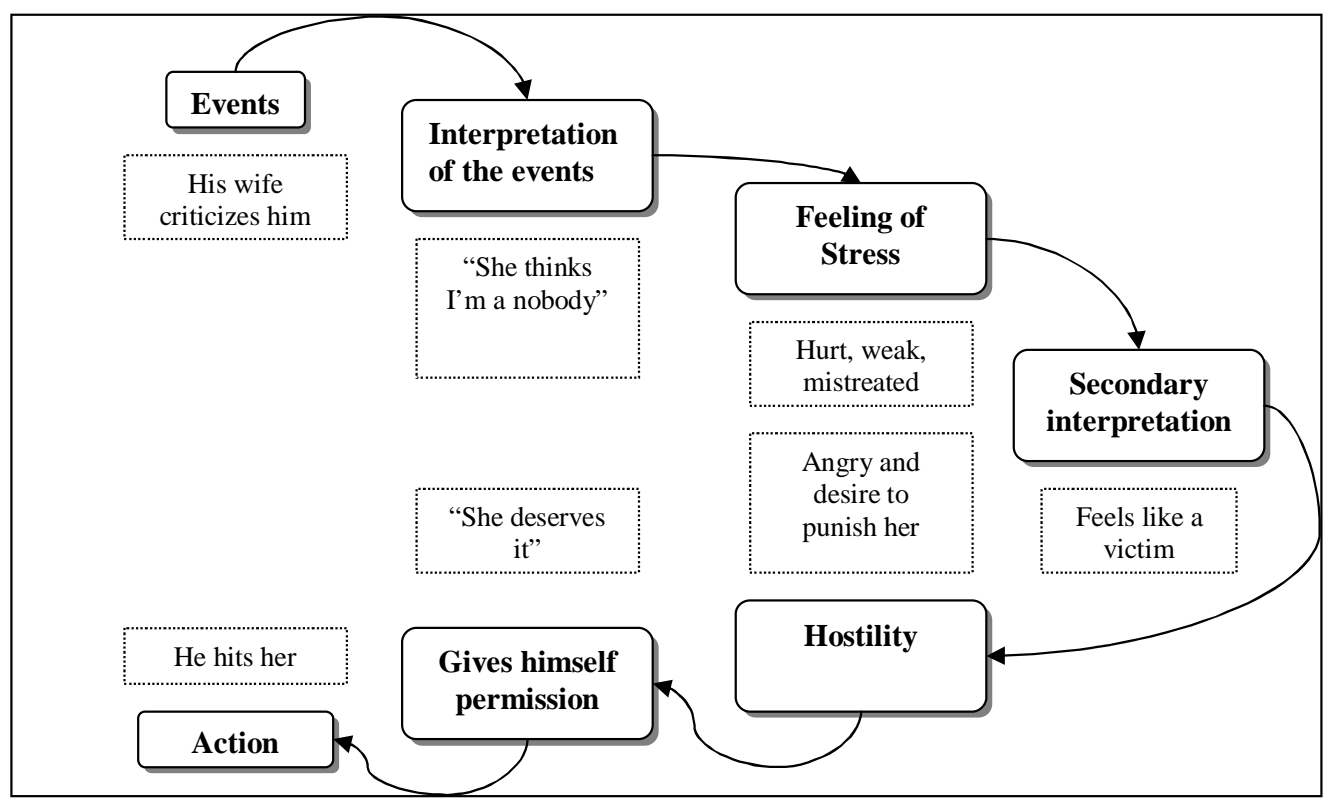

Fig. (2). Legitimacy of our violent response sequence (after Beck \& Pretzer, 2005, p. 70).

foreigner, subhuman, etc), the violent feeling intensifies and inhibitions towards violence and murder are reduced. When one is "hot", i.e. angry or irate, thinking becomes more polarized, inhibitions are reduced, and violent impulses increase. Often, the result of this state is disastrous. "In the heat of the moment": individuals or groups in this state can commit violent acts which later they deeply regret. For example, a slight accident or altercation when driving may end in a highly violent incident, and more so if there are weapons involved.

Many of these factors are also involved in so called "cold" violence, the result of preparation and planning. Here the perception (realistic or not) is that we are constantly under pressure, damaged, coerced, corrupted, so the desire for revenge is constant. The mind of the terrorist, of the genocide, or of those who commit acts of violence against people who they do not know show a number of cognitive distortions, such as overgeneralization (a characteristic of one group member is considered to be possessed by all members, for example the outbreak of violence against Moroccans in El Ejido (Spain) in 2000, after the attempted rape of a girl by a Maghreb). Or dichotomous thinking: they are bad, we are good. Or thinking with tunnel vision: we focus on one aspect of the problem, ignoring the information and experiences that contradict our view.

Dichotomous thinking combined with the demonization of the other comprises a self image of the other which is really explosive. This image then feeds back to the hater making the perception of the other as a demon even stronger. Sometimes the cultural or family context feeds these tendencies to dehumanize the enemy, making it easier for hatred to persist and violence to be used. Belonging to a sub group that promulgates hatred and violence against the enemy reinforces these distortions even more. As Echeburúa (2000) noted, pro-ETA youth gangs are cliques where there is no place for ideas, beliefs or opinions that contradict their position on political violence; everything is part of vicious circle, with no beginning and no end. Individual experiences, cogni- tive distortions and ideology can lead to hatred and violence when conditions are favourable.

\section{BEYOND STERNBERG'S THEORY OF HATE}

R. Sternberg has recently reflected on hatred from a strictly psychological point of view. He developed his duplex theory of hatred (Sternberg, 2005, p. 69) whose basic tenets are:

\section{Hatred is psychologically related to love.}

2. Hatred is not the opposite of love, nor is it the absence of love. Their relationship is quite complex.

3. Hatred, like love, has its origins in personal stories that characterize our emotions.

4. Hatred, like love, can be described as a triangular structure whose origin is these personal stories: the components of the structure are the negation of intimacy, passion and commitment.

5. Hatred is one of the major mechanisms that triggers acts of great violence (massacres, terrorism, and genocide).

As we saw above, the components of hatred are the negation of intimacy (distance), passion and commitment.

Distancing or denial of intimacy in hatred leads to repulsion and aversion to the other. Intimacy seeks a connection with the other. Its denial seeks detachment. We need to distance ourselves from the other to repudiate them. This repulsion may arise from certain characteristics of the person (racial, religious) or actions (treachery, deceit), or propaganda extolling certain characteristics or actions and thus turning the other into sub human or inhuman. Like intimacy in love, in hatred these feelings tend to develop slowly and disappear slowly.

Passion in hatred can arouse feelings of anger and fear. This fear or anger is manifested intensely like a response to a 
threat. It appears as an immediate response to avoid a perceived threat.

Commitment in hatred is characterized by ideas of devaluation and reduction of the human characteristics of an individual or group. The goal of those who promote hatred of the other is precisely to get their group to perceive the other as sub human and to devalue him or her. Sometimes this is achieved through organized schemes of "education", even at school; it is authentic brainwashing.

The combination of these three components form different types of hatred (seven) described in nominal categories. Some types may overlap with one another:

1. Accepted hatred. Denial of intimacy only. The hater hates the other, but does not want to act against him.

2. Hot hatred. Only passion (anger, fear). Extreme feelings of hatred toward someone who is seen as threatening; the reaction may be to attack or escape. A traffic incident can be an example of this hot hatred.

3. Cold hatred. Only feelings of devaluation or commitment. Something is wrong with the members of the hated group. We have been indoctrinated to characterize this group as the axis of evil, or the evil empire, as the USSR was called.

4. Burning hatred. There is commitment and passion. Characteristic of the hatred towards a group. They are seen as sub human or inhuman and threatening, and something must be done to reduce that threat. The hated group may change from time to time.

5. Simmering hatred. There is denial of intimacy and devaluation of commitment. The individual is seen as unpleasant and always will be. Premeditated killings are sometimes a result of this hatred.

6. Furious hatred. There is passion and devaluation of commitment. There is a feeling of revenge towards the person. These people have always been a threat and always will be. Mass violence often has this feature.

7. All-embracing hatred. There is denial of intimacy, devaluation of commitment and passion. The result is the need to annihilate the other.

Hatred is related to other psychological constructs. It may be motivated by feelings of envy, or jealousy. Intelligent people are not excluded from feeling hatred, despite it being a useless feeling, and harming the very person who hates. Stalin and Milosevic certainly were smart people, despite unleashing planned and conscious massacres. It does not seem compatible with wisdom, because this always involves a balance between personal and interpersonal interests, serves the common good and transcends individual interests. People involved in feelings of hatred that cause harm to others intentionally, are not able to experience those feelings of inter and intra personal appreciation.

The question to ask ourselves is how a person feeling such intense hatred can live with himself. And the answer is that in asking this question, we confuse the roles such people play. A murderer can come away from an act of ethnic cleansing, and then be a loving husband and a good father to his children. Such people morally disengage from their ac- tions and create excuses for the hatred they feel, or the suffering that they have consciously caused.

\section{HATE AND VIOLENCE}

The Penal Code describes punishable behaviour at a specific time and place, but does not really serve to regulate human behaviour. What prevents the breaking of the valid rules of coexistence is moral consciousness (Garrido, 2005). When you have this kind of consciousness, going against an ethical principle causes an unpleasant sensation, a kind of inner unrest. This can be considered a certain sense of guilt or shame for what has been done. Guilt therefore has an adaptive function, and its purpose is to avoid situations that generate it, or help us to use behavioural repair strategies to avoid remorse.

Clearly this process is disturbed in violent people. And one of the mechanisms of this disturbance is related to $\mathrm{fa}$ naticism, blind adherence, uncritical thinking, a dogmatic idea excluding all information that is inconsistent with the dogma. Fanaticism dilutes empathy, awareness of others' suffering, and feelings of guilt towards the object of our hatred. Fanaticism can defend ideas which are widespread in an area of political radicalism such as "the socialization of suffering." Behind this attitude lies the failure of the construction of empathy in the individual. Sometimes crazy ideas, classed as blind faith, involve the over-valuation of an idea which has a special place in these people's cognitive framework, and which modulates their life emotionally. It also uncritically directs their behaviour, both violent (which finds its excuse and justification in such ideas) and nonviolent. Violence and fanaticism are inseparable travelling companions. Not only are they so in the absolute certainty of the truth, but also in the need to impose it because there is no other. And if this imposition causes pain to others, it is undervalued, collateral damage; a necessary evil justifying a higher end. Furthermore, fanaticism helps violent people survive, without being tormented by feelings of guilt.

The violent fanatic is also a member of a micro social group where his/her crazy ideas feed. Group members live almost exclusively linked together. Fanaticism is not usually found among the best educated people, given that it is incompatible with critical judgment (Echeburua, Corral, \& Amor, 2003). The fanatic lives in a "niche" without being touched by logical reasoning. Sometimes only the experience of very dramatic life circumstances can break this irrational shell, such as the violent death of a group member, years in prison ... and not always. The result is a real example of brainwashing, accompanied by a nonexistent reality, which leads to the generation of hatred, and whose breeding ground Echeburúa (2000, p. 11) has summarized exceptionally well:

1. Some psychological risk factors: emotional immaturity and dependence, impulsiveness and the seeking of strong sensations in many teenagers. And in some cases in a paranoid personality, whose characteristics are well defined: rigidity of thought, pathological mistrust, emotional poverty, excessive aggressiveness and excessive pride.

2. The accumulation of personal frustration, generating poor self-esteem. He/She blames others for this accumulation of misfortunes and enters a moral vacuum. In this con- 
text, it can be very attractive to go into a group where one is welcomed and valued, even praised and treated as a hero for behaving bravely (i.e., violently), especially when in your daily life (family, school, friends ...) you are mediocre. It is not uncommon to generate idealized expectations that violence and the "revolutionary" objective will solve existing personal problems.

3. The family and educational context sometimes come together to provide a distorted reality, attributing problems to others ("It's all their fault"). Even more so when a member is in jail, and is classed as a hero in their environment.

4. The peer group. They are emotionally contagious; they share behaviours and ideals that strengthen the bonds between them. The gang provides an organized context for their time, with specific activities where everyone participates and that make the person feel responsible and valued. That group is always the same: impervious to outside influences. They only go to certain places, only read certain information, participate in the same activities, have fun and even find a partner within the members of that group. That way there is no possible external contamination. In this context, some violent actions such as social vandalism generate great emotional excitement, and serve to obtain approval and social recognition of the group. There are few adverse consequences, because such vandalism often goes unpunished. It is no wonder that in this context, group members show more and more arrogance.

\section{THE IRONY OF THE SOLUTIONS}

Complex problems do not respond to simple solutions. So the alternatives are not easy. No doubt the family and school education plays a major role. In childhood and adolescence the attitudes of intolerance - impregnated with hatred - are formed, and these are extremely difficult to eradicate later. Learning conflict resolution based on negotiation and compromise seems essential, in addition to adopting intellectually and morally combative attitudes against violence.

But things are not so easy. As Laporta (2006, p.12) noted, we are insistently asking schools and teachers to deal with our children in all aspects. We start early childhood education earlier and earlier, and demand access to childcare even in the holiday season. We increasingly use summer schools, camps, etc., demanding that schools remain open in order to "park" our children. Eating at home is an exception; it is unthinkable in today's urban society to have a family meal at midday. "At this rate, the family that our reactionary clergyman talks about will live with their children on public holidays and twenty days of summer holiday. The rest will simply be sleeping under the same roof. During this time they will be looked after by the teacher, who now will also take care of the new task of citizenship education", undoubtedly essential in order to learn to respond to conflict without resorting to violence.

Many of the solutions to control the rise of hatred and consequences in children and adolescents that we have been discussing are taught in school on a daily basis, in one way or another. But we are faced with the ironic situation that we offer very few positive family and social references. The teacher strives to teach students to respect authority when "teachers are removed of their authority on the slightest pretext". Sometimes the parents themselves publicly denigrate their children's teachers. The school teaches them to renounce violence "whilst they breathe in the latent aggressiveness in the media and everyday experiences." They try to instil them with the use of conflict resolution strategies based on negotiation and compromise. The teacher strives to encourage them to consider the importance of dignity and respect for other people, "while television commercials abound showing people degrading themselves and demeaning others." They try to teach minimum rules of conduct and civility, when their idols are football players too many times showing non self-controlled behaviours. Or carry out activities to promote gender equality, but maybe at home too often the father still watches the TV while the mother washes the dishes. Tolerance is another idea that teachers try to instil in school, while at home so often the foreigner or the immigrant is denigrated.

Laporta (op.cit) concludes, "the irony is that the school can look like an educational oasis; a possible refuge of enlightenment in the middle of a gale of ignorance (...). It is precisely teachers who are in charge of defending the little everyday bastion of civility and enlightenment, and on whom we place ever increasing responsibilities. Let's see if one of these days we think to call a demonstration in favour of them. You would see few union members, fewer politicians and no bishops, but it would be a true demonstration for better education. That is the education which we ask others to undertake for us, and which we then spoil afterwards."

Those ideas are supporting some of the new research lines about hatred causes and links with violence. From our point of view, there are three research topics in this area. Firstly, the analysis of the vulnerability's family and personal factors and protection factors that care for uncontrolled development (Ballet, Bhukuth, \& Hamzetta, 2012; Gudiño, Nadeem, Kataoka, \& Lau, 2012). Second, what social events trigger violent behavior such as xenophobia, fanaticism ideology, dangerous social space (poor and degraded neighbourhoods). This context make evidence the social broken down, and confirm that many people watch our consume society as a shop window. It is very difficult for these people to get any benefices from this society. Finally, there is a productive research about resilience, as a way to get over personal risks. This is especially true for children and teenagers in trouble with the empathy building process (Burt \& Paysnick, 2012).

\section{CONFLICT OF INTEREST}

The authors confirm that this article content has no conflicts of interest.

\section{ACKNOWLEDGEMENTS}

Part of this paper was used during an unpublished lecture at International University Menendez Pelayo Valencia, Spain). 
This work was supported by the Spanish government grants No. EDU2010-19840, EDU2011-2274 and Junta de Andalucia P09-HUM-4918.

\section{REFERENCES}

Anderson, C. A., Carnagey, N. L., \& Eubanks, J. (2003). Exposure to violent media: The effects of songs with violent lyrics on aggressive thoughts and feelings. Journal of Personality and Social Psychology, 84, 960-971.

Ballet, J., Bhukuth, A. \& Hamzetta, B. (2012). Vulnerability to violence of Talibé children in Mauritania. Child Abuse \& Neglect, 36, 602-607.

Beck, A. T. (2002). Prisoners of hate. Behaviour Research and Therapy, 40, 209-216.

Beck, A. T, \& Pretzer, J. (2005). A cognitive perspective on hatred and violence. In: R. Sternberg (Ed.) The Psychology of Hate. (pp. 6785). Washington: APA.

Burt, K. \& Paysnick, A. (2012). Resilience in the transition to adulthood. Development and Psychopathology, 24, 493-505.

Caliskan, D., \& Boratav, H. C. B. (2011). The Impact of Empathy and Gender Differences in Non-Criminal Hate Incidents Towards FTM and MTF Transexuals. (1 p) International Society for Political Psychology (ISPP).

Echeburúa, E. (2000). Por qué y cómo se llega a ser terrorista? Why and how someone turns into a terrorist, (p. 11) El País.

Echeburua, E., Corral, P., \& Amor, P.J. (2003). Evaluation of psychological harm in The victims of violent crime. Psychology in Spain, 7, 1018

Ezequiel, R. S. (2002). The ethnographer looks at Neo-Nazi and Klan groups: The Racism Mind revisited. American Behavioral Scientist, 46(1), 51-57.
Garrido, V. (2005). Que es la psicologia criminologica? What the Criminal Psychology is?. Madrid: Biblioteca Nueva.

Gudiño, O., Nadeem, E., Kataoka, S. \& Lau, A. (2012). Reinforcement sensitivity and risk for psychopathology following exposure to violence: A vulnerability-specificity model in Latino youth. Child Psychiatry and Human Development, 43, 306-321.

Laporta, F. J. (2006). La ironía de la educación ciudadana. The irony of citizen education, El País, 16 August 2006, pp. 11-12.

Meltzoff, A. N. (2011). Social cognition and the origins of imitation, empathy, and theory of mind. Goswami, Usha (Ed), The Wiley-Blackwell handbook of childhood cognitive development (2nd ed.), (pp. 4975). New York: Wiley-Blackwell.

Opotow, S. (1990). Moral exclusion and injustice: An introduction. Journal of Social Issues, 46(1), 1-20.

Post, J. M. (2005). Hatred: The psychological descent into violence. Psychiatric Services, 56, 1463

Salzinger, S., Feldman, R., \& Stockhammer, T. (2002). An ecological framework for understanding risk for exposure to community violence and the effects of exposure on children and adolescents. Aggression and Violent Behavior, 7, 423-451.

Shimoni, H. N., Weizman, A., Yoran, R. H., \& Raviv, A. (2012). Theory of mind, severity of autistic symptoms and parental correlates in children and adolescents with Asperger syndrome. Psychiatry Research, 197, 85-89.

Staub, E. (2005). The origins and evolution of hate, with notes on prevention. In: R. Sterneberg (Ed.) The Psychology of Hate. (pp. 51-66). Washington: APA.

Sternberg, R. J. (2003). A duplex theory of hate: Development and application to terrorism, massacres, and genocide. Review of General Psychology 7(3), 299-328.

Sternberg, R. J. (2005) The Psychology of Hate. Washington: APA.

Received: October 03, 2012

Revised: December 18, 2012

Accepted: December 20, 2012

(C) Navarro et al.; Licensee Bentham Open.

This is an open access article licensed under the terms of the Creative Commons Attribution Non-Commercial License (http://creativecommons.org/licenses/ by-nc/3.0/) which permits unrestricted, non-commercial use, distribution and reproduction in any medium, provided the work is properly cited. 